\title{
Rexinoid NRX 194204
}

National Cancer Institute

\section{Source}

National Cancer Institute. Rexinoid NRX 194204. NCI Thesaurus. Code C74076.

An orally bioavailable synthetic retinoid X receptor (RXR) agonist with potential antineoplastic and anti-inflammatory activities. Rexinoid NRX 194204 selectively binds to and activates RXRs. Because RXRs can form heterodimers with several nuclear receptors (NRs), RXR activation by this agent may result in a broad range of gene expression depending on the effector DNA response elements activated. Rexinoid NRX 194204 may inhibit the tumor-necrosis factor (TNF)-mediated release of nitric oxide (NO) and interleukin 6 (IL6) and may inhibit tumor cell proliferation. This agent appears to be less toxic than RAR-selective ligands. 